\title{
一医師からみたリハビリテーション工学*
}

\section{明石 謙**}

\section{1. はじめに}

リハビリテーション医学を專門とするようになってか ら多くの工学の威力をみてきたが，それと同時に数名の 工学者と親しくなり, 多くのととを学ばせていただい た. 非常に面白かったのは，私が何かを作りたいと思っ て相談すると，使用する条件について想像しなかったほ ど多くの筫問を受けたり，測定器具を使うときの相談に のっていただく場合も，測定条件について詳しい情報を 要求されたてとである. “なるほどエンジニアとはとの ような考え方をするのか”と，想いを新たにするてとが 多かった。 その程度の知識の私が, リ八工学について工 学者を含めた読者を相手に述べるのにはいささか問題が あるように感じたが，普段思っているととを中心に，乙 の小論をまとめてみたいと思う。

\section{2.「工学概論」について}

$\mathrm{ME}$ 学会のリ八工学部門の研究会を, 私が幹事として 催したととがある．時期的には無理があったが，多くの 方々の御協力をいただき，なんとか開催にとぎつけた. その際に“幹事を引き受けたからには工学について少し 勉強してみよう”と思いたち，「工学概論」に関する書 物を探したがなかなか見つからない，そてでまず工学の 定義について，エンジニアとみると手当り次第に質問す るととにした。準備不十分のまま始めたので詳しい数を 示せないが，印象としては次のようなものであった.

(1) “工学の定義なんぞ考えてみたととがない”とい う答が約 $1 / 2$

（2）“工学とは自然科学の，人間生活を豊かにするた ための応用である”という答が約 $1 / 4$

(3) “工学とは人間生活を豊かにするための科学の応 用であり，科学には自然科学に加え社会科学も含ま れる”という答が $1 / 4$

(2)については, 自然科学とはいっても数学のモデルと

* 昭和 59 年 10 月 14 日受付

** 川崎医科大学 リハビリテーション科 Dept. of Rehabilitation Medicine, Kawasaki Medical School.
して表現できるものに限るというのも数人あった.

さて, 次に technologyと engineering の違いについ ても質問してみた．著名な単科大学である MIT のよう に, 名称に technology のついている大学もあり, 工学 者といえば technologist とでもいうのかと思ったとて ろ, 工学関係者は一様に engineer と呼ばれることを希 望され, また, engineering が工学であるとおっしゃる のである. -ology がついているので technology のほう が工学の訳語としてはよいのではないかと思ったが, 手 許の辞書では工学は engineering と揭載されており, technology は工業技術, 応用科学などに混じって, 工 学の語もないわけではない。しかし technologist は技 術学者などという正体のはっきりしない訳語があるのみ で，工学者の語は見あたらなかった。

このような無意味とも思える質問を絽り返している間 も, 書店で執拗に「工学概論」を探し求めていたとこ ろ，棚沢氏の「工学と技術の本質」”を見つけたので早 速買い求めて通読した，全部が十分に理解できたわけで はないが，たいへん興味深かった。氏によれば，“狭義 の工学”を technology の定義とし，とれが応用科学の 一部であるのに対し，乙れに工業技術が結びついたもの が “広義の工学”すなわち engineering であるという。 一応てれで納得したが，さらに同書中にシステム工学の 簡単な紹介があった。これについては後で触れる。

\section{3. 現在までのリハ工学}

現在までのリ八工学に関する発表をみると, 次の 3 つ の分野に集中していることがわかる.

（1）リ八機器の作製最も理解されやすい分野で ある. 障害をもつ人に便利な機器を提供し, 能力改善に 結びつけようというもので, 頸賄損傷による四肢麻痺の 患者に対する顎コントロールの電動車椅子のようなもの である.多くの人々はリ八工学すなわちリ八機器の開発 と考えているのではあるまいか. 加倉井氏のリ八工学に 関するアンケートの報告 ${ }^{2}$ にもそれが示されており，機 器以外のものといえば歩行分析があげられている程度で ある.とれらに対し，氏は hardware 指向型の動向と述 
べている. 1981 年に開催されたリハビリテーション工学 国際セミナー3) でも，内容はリ八機器に関するものばか りであった。なお，機器といっても日常生活動作を助け るものに限らず, スキー, 楽器など, 生活を豊かにする ものから訓練用機器まで幅広く開発の対象とされてお り，そのうちのいくつかはすでに活用されている。

（2）测 定 盛んに行われているのは歩行分析で ある. 特に義足や下肢装具の開発に関する研究から, ど れだけ正常に近い歩行ができるかということが興味の中 心となったてともあった. 歩行を関節角度の変化で招え ようとするものや, 力, 特に床反力で現そうとするもの など, 多くの興味ある結果が次々と発表されてきた。歩 行に限らず, 上肢の筋力とか運動の反応時間, 手指動作 での関節の動き, バイオフィードバックなど, 多くの測 定に工学の力が発揮されている.

（3）測定值の処理 15 年ほど前, 宮城県拓杏園の 今田氏の研究室を訪問したときに，歩行の測定結果を直 ちに微分してみせていただき，たいへん驚いたてとがあ る. その後, 電気の回路に積分回路と加微分回路という ものがあるというととを知り, 加速度計で取り出した電 流を積分回路を通して速度の変化に直して観察したてと がある.てれらはでく原始的な例であるが，何らかのか たちで変量を取り出したときに，それを処理するてとに より別のかたちでデータをみるてとができる.しかし， 他に工学の活躍できる分野はないのだろうか.

\section{4. システムエ学の導入}

前に触れた棚沢氏の著書に示してあったシステム工学 について少し述べてみたい. 先入穓として, システム工 学は何となく面白そうな感じがしていたが，たまたま近 藤次郎氏の「システム工学とは何か」と渡辺茂氏らの 「オペレーションズリサーチ入門」の NHK ブックス 2 冊を手に入れた．私のような門外漢にも理解しやすい ように，よく書かれている本である，そして“てれがど うしてリ八医学に応用されていないのだろうか”を思う ほど示唆に富んだものだった。思いっく例を 2,3 あげ てみたい。

「積最大の決定」では, 制御変数 $\mathrm{x}$ を増加させると娍 少する効果 $\mathrm{m}(\mathrm{x})$ と増大する効果 $\mathrm{n}(\mathrm{x})$ があるとき, れら両者が折りあって最大の効果を発揮しうるのは， れらの積, つまり $\mathrm{m}(\mathrm{x}) \cdot \mathrm{n}(\mathrm{x})$ が最大となるように $\mathrm{x}$ を決定すればよい，たとえば，1人のセラピストの治療 する患者数は限度内で多いほど収入は多くなるが，患者 の治療に対する意欲が小さくなると考元れば，患者の意 欲を失うことなく最大の収入をうる場合に用いることが
できないだろうか.

発病してそれほど時間の経っていない右利きの右片麻 瘦患者の原職復帰の可能性, 庇護職場 への就職の可能 性, 家庭内での $\mathrm{ADL}$ 自立等を $\mathrm{P}_{1} \sim \mathrm{P}_{3}$ などと考えたと き，利き手交換の訓練，ADL 訓練，歩行訓練をそれぞ れ $\mathrm{E}_{1}, \mathrm{E}_{2}, \mathrm{E}_{3}$ として, 各々の訓練にどれだけ時間をかけ るか（重点をおくか）に上り，投資計洒の決定理論の応

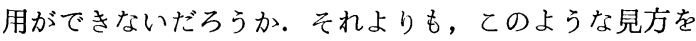
すれば，今までのリ八治療はいつも無計画に総花的な治 療のみを行っているのではないか，という反省も生まれ $\tau<る$.

我々は，脳卒中患者の歩行に関するリハプログラムを フローチャート化し，各々に必要とした時間コストを記 入し，結果として得られた歩行能力と比較した。乙れは PERT 法と呼ばれる手法を応用したものだが，それによ って傾斜台訓練がダミ一点であるてとや，マット訓練に 要する時間がだいたいの趨势を決定していることがわか り，てれを逆に使って歩行に関する予後の推定を斌み上 うとしている.

以上，思いっくままに例をあげたが，乙れらの考え方 の是非は別として, 工学がリ八医学の発展に貢献しうる 分野のひとつと考えてよいのではなかろうか.

\section{5. おわりに}

以前から, 医学と工学の協力の必要性が強調されるむ きがあるししかし医師が工学側に対してもっている認識 または期待している事柄と, 各々の工学者が医療側に提 供できること，またその逆も含め，大きな喰い違いがあ ることをまず指摘したい，私の立場からすれば，工学者 は医療側に何が提供できるかを積極的に知らせる必要が あるだろう。逆に医療側は，医学という壁に囲まれた世 界で行っている自給自足体制を見直し，何が欠けている かを見いださなければならない，特に，リ八医学は若く 発展途上にあり，しかも総合医学としての傾向が大きい ところから，外界に大きく眼を開き貪欲に外界の力をと り入れて, 本来の目的, つまり個々の患者の最もよいか たちでの社会復帰が達成できるよう努力すべきである。

\section{参考文献}

1）棚沢 泰：工学と技術の本質, 第 2 版, 養賢堂, 東京, 1981 .

2）加倉井周一: 臨床サイドからみたリ八工学への要 望と今後の課題，リ八医学，21(3)，193 197, 1984.

3） REIS-'81 組織委員会: REIS-'81 リ八工学国際 セミナー（1981）講演論文集, 1981. 